DOI: 10.17707/AgricultForest.65.1.22

\author{
Katarína HOZÁKOVÁ*, Jozef BUJKO, \\ Klára VAVRIŠÍNOVÁ, Július ŽITNÝ ${ }^{1}$
}

\title{
EVALUATION OF THE FACTORS AFFECTING THE GROWTH INTENSITY OF CHAROLAIS CALVES
}

\begin{abstract}
SUMMARY
The aim of study was to evaluate the growth indicators in total of 1,986 purebred Charolais calves in relation to the sex, year of birth, birth season of the calves and also dam's parity. At the same time, the object of work was to evaluate cows' longevity. We found higher values of live weight in bulls $(\mathrm{P}>0.05)$, the occurrence of twins showed lower birth weight $(\mathrm{P}<0.001)$ and weaning weight $(\mathrm{P}>0.05)$. The spring season of calving had an influence on lighter offspring in birth weight $(\mathrm{P}<0.001)$ as well as in pre-weaning period $(\mathrm{P}<0.001)$; the heaviest calves were born in the winter calving season. Calves born to primiparous cows were markedly lighter at birth $(\mathrm{P}>0.05)$, at the age of 120 days $(\mathrm{P}>0.05)$, and also at the weaning $(\mathrm{P}<0.05)$ than those born to older cows. The linear model characterized by the coefficient of determination for all fixed effects was $\mathrm{R}^{2}=0.714862 \%$ for birth weight (BLW), $\mathrm{R}^{2}=0.375164 \%$ for weight at 120 days (LW120) and $\mathrm{R}^{2}=0.473550 \%$ for weaning weight (LW210). On the basis of the results, we can observe the increased growth performance of calves over the years, pointing to the adaptation of Charolais to conditions in Slovakia.
\end{abstract}

Keywords: calves, cattle, coefficient of determination, Charolais, traits of growth.

\section{INTRODUCTION}

Breeding of suckling cows in Slovakia has an increasing tradition despite of the unfavourable economic situation. Increasing interest in cattle breeding results from trends of the society, especially in the consumption of quality raw materials. At the present, 11 specialized purebred cattle breeds are kept in Slovakia. The most numerous are Charolais and Limousine.

In meat production, the most important parameter is an excellent growth potential of calves represented by the live weight. In Slovakia, the live weight is determined at 120, 210 and 365 days of age. The most economically important is a live weight gained at 210 days, i.e. the weaning weight. Calves growth ability, such as the weaning weight is affected by many genetic as well as non-genetic

\footnotetext{
${ }^{1}$ Katarína Hozáková *(corresponding author: xsupekovak@uniag.sk), Klára Vavrišínová, Department of Animal Husbandry, Slovak Agricultural University in Nitra, SLOVAK REPUBLIC; Jozef Bujko, Július Žitný, Department of Genetic and Breeding Biology, Slovak Agricultural University in Nitra, SLOVAK REPUBLIC

Notes: The authors declare that they have no conflicts of interest. Authorship Form signed online.
} 
factors (Toušová et al., 2014). The aim of many studies was to evaluate the influence of factors such as: the breed (Bene et al., 2007), the sex of calves including occurrence of twins, the birth season (Krupa et al., 2005; Toušová et al., 2014), the dam's age at calving (Krupa et al., 2005; Szabó et al., 2006) as well as the sire (Özlütürk et al., 2006).

Modern selecting programs tend to increase the body weight and body size at attaining maturity. The positive relationship between growth traits and live weight at maturity favourably affects the weight gains and therefore amount of muscular tissue. Just selecting cattle breeds aimed to enhance not only the quantity, but also the quality of meat with the respect to consumer preferences (Albertí et al., 2008).

The meat attributes including objectiveness and measurability of carcass. The interest of the meat industry is tended to accelerate the growth of calves and to achieve the slaughter weight earlier. Excellent maternal properties of milking cows are used in crossbreeding with beef cattle for rearing calves to greater weaning weights (Coleman et al., 2016).

According to Eriksson et al. (2004) there is a direct genetic continuity between the dam's age at calving and the calves' birth weight. Likewise, the degree of carcass fatness has a negative effect on the birth weight and the calving difficulty.

The calving ability and calves vitality are functional traits of the cow's lifespan. In recent years, the selection criteria include increasing the longevity of milking cows such as beef cows (Róźańska-Zawieja et al., 2014).

The aim of this work was to evaluate the indicators of the growth of purebred Charolais calves kept in different farming conditions in Slovakia. At the same time, the paper examines factors affecting selected utility parameters of Charolais breed. In the next part, the study examines the longevity of cows as well as numbers of reared calves.

\section{MATERIAL AND METHODS}

The material of nine herds of Charolais breed was provided from the database of Breeding Services of the Slovak republic (B.S. SR, S.E., 2017). A total of 1,986 calves (bulls $=793$; heifers $=1,116$; twins $=77$ ) born between 2010 and 2016 were observed during evaluation.

In the monitored herds the mating system included seasonal mating and artificial insemination as well, 95 calves were born after embryo transfer. Subsequent calving season was distributed within individual herd throughout the year. During the entire grazing period from May to October the calves remained on the pasture with the cows. All animals were pasturing during the entire period and at the end of the grazing period were subsequently housed together in the winter blocks. The animals - bulls, sukler cows and monitored calves were during the winter period fed a feed ration based on hay, straw, alfalfa silage and maize silage in ad libitum amount. 
In accordance with the Methodology of Performance Recording for Beef Cattle used to control the growth ability of suckler cows (Darnadiová and Debrecéni, 2009) the study evaluates the birth weight (BW), weight at 120 days (W120) and 210 days (W210). For the evaluation of the cows' longevity, the lifespan and the age at culling were the analyzed characteristics. Furthermore, the number of calves reared per a cow was calculated.

The basic statistical and variability characteristics (least square means, standard deviations) were evaluated using the Statistical Analysis System (SAS) version 9.3 (TS1M2) Enterprise Guide 5.1. (SAS INSTITUTE Inc., 2011). The mixed procedure was used for the final analysis. The value of statistical significance $(\mathrm{P})$, the value of the F-test and the coefficient of determination $\left(\mathrm{R}^{2}\right)$ of the above mentioned growth parameters were evaluated with its relation to: the sex of the calves (bulls, heifers, twins), calving season, year of birth, and dam's parity. For the impact of the verification the mixed model equation was used:

where:

$$
\mathrm{Y}_{i j k l m}=\mu+\mathrm{SEX}_{i}+\mathrm{BS}_{j}+\mathrm{YB}_{k}+\mathrm{LR}_{l}+\mathrm{e}_{i j k l}
$$

$\mathrm{Y}_{i j k l m}$ - depended variable (BLW, LW120, LW210)

$\mu$ - mean value of depended variable

$\mathrm{SEX}_{i}$ - fixed effect of $i^{\text {th }}$ sex of calf

$\mathrm{BS}_{\mathrm{j}}$ - fixed effect of $j^{\text {th }}$ calving season

$\mathrm{YB}_{\mathrm{k}}$ - fixed effect of $k^{\text {th }}$ year of birth

$\mathrm{LR}_{1}$ - fixed effect of $l^{\text {th }}$ class of dam's parity

$\mathrm{e}_{i j k l}$-random error

During the evaluation the calves were into four groups according to the calving season: winter calves (A) born from December to February, spring calves (B) born from March to May, summer calves (C) born from June to August, autumn calves (D) born from September to November divided. According to the sex calves were into bulls and heifers divided. The occurrence of twins was also recorded and therefore the calves were divided into male twins, female twins and mixed twins. There were seven levels of the year of birth (2010 - 2016) and six levels of dam's parity $\left(1^{\text {st }}\right.$ lactation, $2^{\text {nd }}-3^{\text {rd }}$ lactation, $4^{\text {th }}-6^{\text {th }}$ lactation, $7^{\text {th }}-9^{\text {th }}$ lactation, $10^{\text {th }}$ lactation, and subsequent). Statistical evaluations of the differences between traits were tested at the levels of statistical significance: ${ }^{+} \mathrm{P}<0.05,{ }^{++}$ $\mathrm{P}<0.01,{ }^{+++} \mathrm{P}<0.001$ or $^{-} \mathrm{P}>0.05$.

\section{RESULTS AND DISCUSSION}

The linear model is described in Table 1. The coefficient of determination of observed traits with all fixed effects ranged from $\mathrm{R}^{2}=0.010231 \%$ with relation to the $\mathrm{W} 210$ to $\mathrm{R}^{2}=0.604172 \%$ in relationship to the BW. The most important factor was the effect of herd $\left(\mathrm{R}^{2}=0.283454 \%\right.$ for $\mathrm{W} 120$ to $0.604172 \%$ for $\left.\mathrm{BW}\right)$, the effect of sex of calves $\left(\mathrm{R}^{2}=0.118623 \%\right.$ for $\left.\mathrm{BW}\right)$, the effect of the year of birth $\left(\mathrm{R}^{2}=0.063582 \%\right.$ for $\mathrm{W} 210$ to $0.079556 \%$ for $\left.\mathrm{W} 120\right)$. The statistical 
significance of the all mentioned factors were $\mathrm{P}<0.001$. According to various authors, the effect of the herd-year-season is the most significant factor with higher variability (Krupa et al., 2005; Stádník et al., 2008). Our results are similar to those of Krupa et al. (2005), who showed the highest influence of the effect for BW $\left(\mathrm{R}^{2}=0.867 \%\right)$.

Table 1. The influence of the factors affecting BW, W120 and W210 in selected herds of Charolais breed

\begin{tabular}{|c|c|c|c|c|c|c|c|c|c|c|}
\hline \multirow{2}{*}{$\begin{array}{l}\text { Sources } \\
\text { of } \\
\text { variance }\end{array}$} & \multirow{2}{*}{$\mathrm{DF}^{\mathrm{a}}$} & \multicolumn{3}{|c|}{$(\mathrm{BW})$} & \multicolumn{3}{|c|}{ (W120) } & \multicolumn{3}{|c|}{ (W210) } \\
\hline & & $\mathrm{MS}^{\mathrm{b}}$ & $\mathrm{v}^{\mathrm{c}}$ & R-Square ${ }^{\mathrm{d}}$ & $\mathrm{MS}^{\mathrm{b}}$ & $\mathrm{v}^{\mathrm{c}}$ & R-Square ${ }^{\mathrm{d}}$ & $\mathrm{MS}^{\mathrm{b}}$ & $\mathrm{v}^{\mathrm{c}}$ & R-Square $^{\mathrm{d}}$ \\
\hline Herd & 9 & 4291.64 & 10.04 & $0.604172^{+++}$ & 326858.21 & 46.07 & $0.283454^{+++}$ & 1270755.66 & 549.99 & $0.393660^{++}$ \\
\hline $\begin{array}{l}\text { Sex of } \\
\text { calves }\end{array}$ & 7 & 1083.37 & 14.97 & $0.118623^{+++}$ & 75356.56 & 52.99 & $0.050828^{+++}$ & 146464.78 & 63.03 & $0.035290^{++}$ \\
\hline $\begin{array}{l}\text { Calving } \\
\text { season }\end{array}$ & 3 & 1099.40 & 15.51 & $0.051591^{-}$ & 60159.28 & 53.86 & $0.017390^{+++}$ & 422857.57 & 62.69 & $0.043665^{++}$ \\
\hline $\begin{array}{l}\text { Year of } \\
\text { birth }\end{array}$ & 6 & 262.93 & 15.74 & $0.024676^{+++}$ & 137606.99 & 52.17 & $0.079556^{+++}$ & 307867.36 & 62.08 & $0.063582^{++}$ \\
\hline Parity & 11 & 108.10 & 15.71 & $0.019782^{+}$ & 11644.25 & 51.95 & $0.013641^{+}$ & 25853.95 & 64.38 & $0.010231^{-}$ \\
\hline
\end{tabular}

agrades of freedom, ${ }^{\mathrm{b}}$ mean squares, ${ }^{\mathrm{C}}$ coefficient of variation, ${ }^{\mathrm{d}}$ coefficient of determination $\left(\mathrm{R}^{2}\right)$;

${ }^{+} \mathrm{P}<0.05,{ }^{++} \mathrm{P}<0.01,{ }^{+++} \mathrm{P}<0.001$ or $^{-} \mathrm{P}>0.05$

The values given in Table 2 represent the effect of the herd, sex, birth year, calving season as well as dams' parity. A statistical significance for all growth traits was detected of the level $\mathrm{P}<0.001$ in relation to the herd, sex, birth year; and the level $\mathrm{P}<0.05$ in relation to the parity. Our findings are similar to Szabó et al. (2006) who found the significant effect $(\mathrm{P}<0.05)$ of sire, herd, age of dam's calving, birth year, season and sex of calves on the weaning weight. The growth ability of beef breeds is one of the most important parameters influencing beef production. Charolais calves show relatively high birth weight (Mujibi and Crews, 2009), statistically similar to Limousine and Blonde d' Aquitaine calves (Szabolcs et al., 2013). According to Eriksson et al. (2004) high birth weight is associated with the gestation length and better vitality of calves. Higher growth abilities of calves are due to higher birth weight (Koch et al., 2004). On the other hand, the authors Özlütürk et al. (2004) report for Charolais higher final weight and heavier carcasses at a lower initial weight. The significance of the parity was at the level $\mathrm{P}>0.05$ only for W210. 
Table 2. The statistical evaluations of BW, W120 and W210 in selected herds of Charolais breed

\begin{tabular}{|c|c|c|c|c|c|}
\hline Traits & Herd & Sex of calves & Calving season & Year of birth & Parity \\
\hline BW (kg) & $355.12^{+++}$ & $38.03^{+++}$ & $35.94^{+++}$ & $8.35^{++}$ & $3.48^{+++}$ \\
\hline W120 (kg) & $86.85^{+++}$ & $15.13^{+++}$ & $11.69^{+++}$ & $28.51^{+++}$ & $2.39^{++}$ \\
\hline W210 (kg) & $142.54^{+++}$ & $10.34^{+++}$ & $30.17^{++}$ & $22.40^{+++}$ & $1.78^{-}$ \\
\hline
\end{tabular}

$+\mathrm{P}<0.05,++\mathrm{P}<0.01,+++\mathrm{P}<0.001$ or $-\mathrm{P}>0.05$

Pursuant to the effect of the sex of calves (Table 3), bull calves were heavier than heifers in all of the monitored growth parameters $(\mathrm{BW}+2.15 \mathrm{~kg}$, $\mathrm{W} 120+26.45$, W210 $+37.28 \mathrm{~kg}$ ), unfortunately the significance was at the level $\mathrm{P}>0.05$. These differences are according to various authors important for the survival of the calves at the weaning period and for the growth rate before weaning as well, which is higher for Charolais and Simmental calves (Szabó et al., 2006). The majority of works recording growth abilities of the calves, including Krupa et al. (2005), Stádník et al. (2008) report the highest birth weight for bulls, followed by male twins and heifers. This does not correspond with our findings; male twins were the lightest $(27.27 \mathrm{~kg}$ ). Moreover we found different results of weaning weight which is the highest for bulls and also similar for male twins and female twins (183.90 and $185.79 \mathrm{~kg}$, respectively).

In relation to the occurrence of twins (Table 3), differences of live weight were higher at birth (8.61 kg) and at weaning as well (30.78 kg), when differences were significant. These results are in agreement with Stádník et al. (2008). Despite the lower birth weight and lower weaning weight, in accordance with Davis et al. (1989) twins produce more weight per cow on sale. Birth of twins in the herds with meat production is a desirable attribute and may be important for systematic dam breeding (Stádník et al., 2008).

Relating to the effect of the dams' parity on birth weight given in table 4, we could summarize that the birth weight increase with the parity, however results were non-significant $(\mathrm{P}>0.05)$. The largest numbers of calves were born to cows on the second and third lactation (39.11\%), while the lowest numbers were born to the oldest cows $(0.52 \%)$. The offspring from oldest cows reached in average $5.12 \mathrm{~kg}$ heavier BW than calves born to primiparous cows. It is necessary to select sires and their usage for mating of heifers to avoid dystocia and improve the birth weight (Özlütürk et al., 2006). The highest average values of pre-weaning period were determined in offspring of cows with tenth and subsequent parity, the differences varied from $2.81 \mathrm{~kg}$ to $37.66 \mathrm{~kg}$. These results point to the lower milking ability of heifers and dams with second parity as well as to their own continuing development. The highest values of W210 reached offspring of the oldest cows ( $\mathrm{P}>0.05)$. These results are similar to those of Szabó et al. (2006), Stádník et al. (2008). 
Table 3. Basic characteristics of BW, W120 and W210 in relation to the sex of the calves and occurrence of singles and twins

\begin{tabular}{|c|c|c|c|c|c|c|c|c|}
\hline \multirow{2}{*}{\multicolumn{2}{|c|}{ Effects }} & \multirow{2}{*}{$n^{a}$} & \multicolumn{2}{|c|}{ BW (kg) } & \multicolumn{2}{|c|}{ W120 (kg) } & \multicolumn{2}{|c|}{ W210 (kg) } \\
\hline & & & $\mathrm{LSM}^{\mathrm{b}}$ & $\mathrm{SD}^{\mathrm{c}}$ & $\mathrm{LSM}^{\mathrm{b}}$ & $\mathrm{SD}^{\mathrm{c}}$ & $\mathrm{LSM}^{\mathrm{b}}$ & $\mathrm{SD}^{\mathrm{c}}$ \\
\hline \multirow{5}{*}{ Sex } & Bull & 723 & $37.01^{-}$ & 5.76 & $150.60^{-}$ & 66.75 & $208.01^{-}$ & 121.57 \\
\hline & Heifer & 1,091 & $34.86^{+}$ & 5.03 & $124.15^{++}$ & 70.91 & $170.73^{++}$ & 119.08 \\
\hline & Male twins & 30 & $27.27^{+++}$ & 5.91 & $127.83^{-}$ & 48.68 & $183.90^{+}$ & 89.91 \\
\hline & $\begin{array}{c}\text { Female } \\
\text { twins }\end{array}$ & 14 & $28.86^{+++}$ & 4.56 & $119.14^{-}$ & 43.98 & $185.79^{-}$ & 86.88 \\
\hline & $\begin{array}{l}\text { Mixed } \\
\text { twins }\end{array}$ & 33 & $30.27^{+++}$ & 6.19 & $148.67^{-}$ & 34.14 & $194.87^{+}$ & 106.97 \\
\hline \multirow{2}{*}{$\begin{array}{l}\text { Occurrence of } \\
\text { singles and twins }\end{array}$} & Singles & 1,909 & $37.77^{++}$ & 5.02 & $129.39^{-}$ & 84.36 & $220.63^{++}$ & 115.74 \\
\hline & Twins & 77 & $29.16^{+++}$ & 5.71 & $136.08^{+}$ & 40.23 & $189.85^{\circ}$ & 97.68 \\
\hline
\end{tabular}

Table 4. Basic characteristics of BW, W120 and W210 in relation to the dams'parity

\begin{tabular}{|c|c|c|c|c|c|c|c|}
\hline \multirow{2}{*}{ Parity } & \multirow{2}{*}{$\mathrm{n}^{\mathrm{a}}$} & \multicolumn{2}{|c|}{ BW (kg) } & \multicolumn{2}{c|}{ W120 (kg) } & \multicolumn{2}{c|}{ W210 (kg) } \\
\cline { 3 - 8 } & & LSM $^{\mathrm{b}}$ & $\mathrm{SD}^{\mathrm{c}}$ & LSM $^{\mathrm{b}}$ & $\mathrm{SD}^{\mathrm{c}}$ & LSM $^{\mathrm{b}}$ & $\mathrm{SD}^{\mathrm{c}}$ \\
\hline $1^{\text {th }}$ & 462 & $34.69^{-}$ & 5.45 & $124.41^{-}$ & 75.26 & $172.20^{-}$ & 124.30 \\
\hline $2^{\text {nd }}-3^{\text {rd }}$ lactation & 747 & $35.28^{-}$ & 5.89 & $135.73^{-}$ & 69.59 & $190.16^{-}$ & 120.35 \\
\hline $4^{\text {th }}-6^{\text {th }}$ lactation & 537 & $35.91^{-}$ & 5.87 & $138.54^{-}$ & 66.41 & $194.34^{-}$ & 116.09 \\
\hline $7^{\text {th }}-9^{\text {th }}$ lactation & 140 & $36.81^{-}$ & 5.02 & $146.65^{-}$ & 61.59 & $181.44^{-}$ & 123.41 \\
\hline $10^{\text {th }}+$ lactation & 14 & $37.43^{-}$ & 3.55 & $162.07^{-}$ & 21.01 & $167.79^{-}$ & 134.63 \\
\hline
\end{tabular}

\footnotetext{
${ }^{\mathrm{a}}$ number of observations, ${ }^{\mathrm{b}}$ least squares means, ${ }^{\mathrm{c}}$ standard deviation; - P $>0.05$
} 
Table 5 describes the effect of the calving year and season on the live weight of calves. A statistical significance of the level $\mathrm{P}<0.001$ was recorded in relation to the calving season for all live weights except W120 ( $\mathrm{P}>0.05)$. Differences of birth live weight in relation to the calving season were nonsignificant $(3.97 \mathrm{~kg})$. Higher and significant differences were determined at W120 and W210 (21.79 kg vs. $61.72 \mathrm{~kg}$ ) in calves born in different season.

Table 5. Basic characteristics of BW, W120 and W210 in relation to the calving season and year of birth

\begin{tabular}{|c|c|c|c|c|c|c|c|c|}
\hline \multirow{2}{*}{ Effects } & & \multirow{2}{*}{$\mathrm{n}^{\mathrm{a}}$} & \multicolumn{2}{|c|}{ BW (kg) } & \multicolumn{2}{|c|}{ W120 (kg) } & \multicolumn{2}{|c|}{ W210 (kg) } \\
\hline & & & $\mathrm{LSM}^{\mathrm{b}}$ & $\mathrm{SD}^{\mathrm{c}}$ & $\mathrm{LSM}^{\mathrm{b}}$ & $\mathrm{SD}^{\mathrm{c}}$ & $\mathrm{LSM}^{\mathrm{b}}$ & $\mathrm{SD}^{\mathrm{c}}$ \\
\hline \multirow{4}{*}{$\begin{array}{l}\text { Season of } \\
\text { birth }\end{array}$} & Winter (A) & 503 & $35.71^{+++}$ & 6.61 & $120.27^{-}$ & 78.02 & $204.79^{+++}$ & 120.09 \\
\hline & Spring (B) & 971 & $36.51^{+++}$ & 4.99 & $142.06^{++}$ & 72.58 & $203.17^{+++}$ & 117.79 \\
\hline & Summer (C) & 244 & $35.58^{+++}$ & 5.01 & $133.86^{-}$ & 61.25 & $143.07^{-}$ & 120.79 \\
\hline & Autumn (D) & 268 & 32.54 & 5.62 & 124.54 & 64.77 & 148.78 & 115.17 \\
\hline \multirow{7}{*}{ Year of birth } & 2010 & 3 & $28.33^{++}$ & 3.21 & $100.67^{-}$ & 87.32 & $199.33^{-}$ & 40.10 \\
\hline & 2011 & 176 & $35.75^{+}$ & 5.33 & $148.78^{+}$ & 65.12 & $245.63^{-}$ & 82.28 \\
\hline & 2012 & 352 & $34.02^{+++}$ & 5.53 & $106.81^{+++}$ & 76.19 & $174.36^{+++}$ & 119.58 \\
\hline & 2013 & 380 & $35.74^{+}$ & 5.60 & $108.88^{+++}$ & 83.48 & $206.25^{+}$ & 99.31 \\
\hline & 2014 & 340 & $36.01^{-}$ & 5.22 & $143.72^{++}$ & 67.26 & $154.46^{+++}$ & 142.87 \\
\hline & 2015 & 472 & $35.88^{+}$ & 5.74 & $142.68^{++}$ & 69.12 & $166.24^{+++}$ & 128.12 \\
\hline & 2016 & 263 & 36.89 & 6.17 & 162.75 & 35.66 & 230.07 & 99.78 \\
\hline
\end{tabular}

${ }^{\mathrm{a}}$ number of observations, ${ }^{\mathrm{b}}$ least squares means, ${ }^{\mathrm{c}}$ standard deviation; ${ }^{+} \mathrm{P}<0.05,{ }^{++} \mathrm{P}<0.01$, ${ }^{+++} \mathrm{P}<0.001$ or $^{-} \mathrm{P}>0.05$

The calves born in winter season were lighter in pre-weaning period than calves born in other seasons. Keeping calves on pasture with their mothers increase beef production effectiveness and give a precondition to a more intensive growth rate with cheaper feeding sources (Crosson, 2015). The majority of calving was recorded in winter (25.3\%) and spring (48.89\%) season, respectively. The offspring born in the winter season reached the significantly highest weaning weight $(204.79 \mathrm{~kg})$, while the lightest calves were born in the 
summer (143.07 kg). Our results are inconsistent with findings of Kovács et al. (1994) where the heaviest calves were born in autumn and Szabó et al. (2006) for summer calves. Over the study period, the highest BW and W120 were recorded in $2016(\mathrm{P}<0.01 ; \mathrm{P}>0.05)$, which is an opposite of the worst year, i.e. 2010 (+8.56 kg and $62.08 \mathrm{~kg}$, respectively). Only the weaning weight was highest in year 2011 (245.63 kg), however results were non-significant. Our results demonstrate the importance of management during different weather and pasture conditions throughout the years.

Table 6 represents the indicators of dams' longevity and number of calves born in the monitored herds. We evaluated an average lifespan of 8.39 years, while the highest value was 17.49 years. The longevity is an important economic trait in beef herds and it is in close relationship with a reproductive performance, while we can expect a high rate of productivity, in average 8-12 years. The most of calves (3.26) were born at the age of 8.39 years. In comparison with Róźańska-Zawieja et al. (2014) we found a longer lifespan of Charolais cows, for about 3.69 years.

Table 6. Basic characteristics of the longevity of Charolais dams and average number of dams' offspring

\begin{tabular}{|l|c|c|c|c|c|c|}
\hline Effect & $\mathrm{n}^{\mathrm{a}}$ & $\mathrm{LSM}^{\mathrm{b}}$ & $\mathrm{SD}^{\mathrm{c}}$ & $\mathrm{v}^{\mathrm{d}}$ & $\mathrm{MIN}^{\mathrm{e}}$ & $\mathrm{MAX}^{\mathrm{f}}$ \\
\hline Longevity of cows & 979 & 8.39 & 2.87 & 34.137 & 2.39 & 17.49 \\
\hline Number of calves & 1910 & 3.26 & 2.13 & 66.15 & 1 & 12 \\
\hline
\end{tabular}

${ }^{a}$ number of observations, bleast squares means, ${ }^{c}$ standard deviation, ${ }^{d}$ coefficient of variation, ${ }^{\mathrm{e}}$ minimum, ${ }^{\mathrm{f}}$ maximum

\section{CONCLUSIONS}

In the context of this study, it can be concluded that the growth ability of monitored beef calves kept in different conditions in Slovakia, was significantly influenced by the sex, year of birth, birth season as well as by the age of dams. In the evaluated file of animals we found the average birth weight $35.935 \mathrm{~kg}$, W120 $137.38 \mathrm{~kg}$ and W210 $189.37 \mathrm{~kg}$. The highest differences in BW were found in relation to the dams' parity $(5.12 \mathrm{~kg})$. The highest differences in W120 were found in the lactation rank and sex of calves (37.66 resp. $31.46 \mathrm{~kg}$ ) and W210 at the birth season factor $(61.72 \mathrm{~kg})$.

The influence of the birth year on live weights of monitored animals signifies an adaptation of Charolais breed to the conditions of the Slovak regions and despite of achieved growth results in the winter birth season, it is important to enforce mating and calving in agreement with the concrete farming conditions. During the evaluation of the lifespan we determined unsuitable results for beef breeds for which a long performance and a high number of offspring is required. 


\section{ACKNOWLEDGEMENTS}

This study was supported by the Scientific Grant Agency of the Ministry of Education, Science, Research and Sport of the Slovak Republic and the Slovak Academy of Sciences (VEGA) (Projects No. 1/0724/16 and No. 1/0742/17).

Authors would like thanks the Breeding Services of the Slovak Republic (B.S. SR, S.E.) for providing data for processing.

\section{REFERENCES}

Albertí, P., Panea, B., Sañudo, C., Olleta, J.L., Ripoll, G., Ertbjerg, P., et al. (2008). Live weight, body size and carcass characteristics of young bulls of fifteen European breeds. Livestock Science, 114(1), 19-30. DOI: 10.1016/j.livsci.2007.04.010

Bene, S., Nagy, B., Nagy, L., Kiss, B., Polgár, J. P. \& Szabó, P. (2007). Comparison of body measurements of beef cows of different breeds. Archiv fur Tierzucht, Dummerstorf, 50(4), 363-373. DOI: 10.5194/aab-50-363-2007

Coleman, L.W., Hickson, R.E., Schreus, N.M., Martin, N.P., Kenyon, P.R., LopezVillalobos, N., et al. (2016). Carcass characteristics and meat quality of Hereford sired steers born to beef-cross-dairy and Angus breeding cows. Meat Science, 121, 403-408. DOI: 10.1016/j.meatsci.2016.07.011

Crosson, P. (2015). How to economically achieve a 365-day calving interval for suckler cows. Retrieved from http://www.agriland.ie/farming-news/how-to-economicallyachieve-a-365-day-calving-interval-for-suckler-cows-teagasc/

Darnadiová, O. \& Debrecéni, O. (2009). Charolais beef breed adaptation to breeding conditions in Slovakia. Adaptácia plemena charolais na chovatel'ské podmienky Slovenska. Acta fytotechnica et zootechnica 3, Slovaca Universitas Agriculturae Nitriae, 81-84. ISSN: 1336-9245

Davis, M.E., Harvey, W.R., Bishop, M.D. \& Gearheart, W.W. (1989). Use of embryo transfer to induce twinning in beef cattle: embryo survival rate, gestation length, birth weight and weaning weight of calves. Journal of Animal Science, 67(2), 301310. DOI: 10.2527/jas1989.672301x.

Eriksson, S., Näsholm, A., Johansson, K. \& Philipsson, J. (2004). Genetic relationship between calving and carcass traits for Charolais and Hereford cattle in Sweden. Journal of Animal Science, 82(8), 2269-2276. DOI:10.2527/2004.8282269x

Koch, R. M., Cundiff, L. V., Gregory, K. E. \& Van Vleck, L. D. (2004). Genetic response to selection for weaning weight or yearling weight or yearling weight and muscle score in Hereford cattle: efficiency of gain, growth, and carcass characteristics. Journal of Animal Science, 82(3), 668-682. DOI:10.2527/2004.823668x

Kovács, A., Szücs, E., Bori, T., Nagynaska, E. \& Vőlgyi Csík, J. (1994). A születési hónap ésa zivarhatása a limousine borjak választási, valaminté veskoriteljes ítményére. ÁllattenyésztésésTakarmányozás, 43(3), 209-211. ISSN 0230-1614

Krupa, E., Oravcová, M., Polák, P., Huba, J. \& Krupová, Z. (2005). Factors affecting growth traits of beef cattle breeds raised in Slovakia. Czech Journal of Animal Science, 50(1), 14-21. DOI: 10.17221/3990-CJAS

Mujibi, F. D. N. \& Crews, D.H. (2009). Genetic parameters for calving ease, gestation length, and birth weight in charolais cattle. Journal of Animal Science, 87(9), 2759-2766. DOI:10.2527/jas.2008-1141

Özlütürk, A., Tüzemen, N., Yanar, M., Esenbuga, N. \& Dursun, E. (2004). Fattening performance, carcass traits and meat quality characteristics of calves sired by Charolais, Simmental and Eastern Anatolian Red sires mated to Eastern Anatolian Red dams. Meat Science, 67(3), 463-470. DOI: 10.1016/j.meatsci.2003.11.022 
Özlütürk, A., Yanar, M., Tüzemen, N. \& Kopuzlu, S. (2006). Calving and preweaning growth performance traits of calves sired by Charolais, Simmental and Eastern Anatolian Red Bulls. Turkish Journal of Veterinary and Animal science, 30(2), 257-263. ISSN: 1303-6181.

http://dergipark.gov.tr/tbtkveterinary/issue/12539/151205

Róźańska-Zawieja, J., Nienartowicz-Zdrojewska, A., Smorag, T. \& Sobek, Z. (2014). Longevity of use and reasons for beef cattle culling in Poland. Medycyna Weterynaryjna, 70(8), 491-496. www.medycynawet.edu.pl

SAS Institute Inc. (2011) Base SAS® 9.3 Procedures Guide. Cary, NC: SAS Institute Inc., Carry. NC. USA.

Stádník, L., Louda, F., Bolečková, J., Benešová, L. \& Matějů, R. (2008). Effect of charolais dam's mating method and parity on growth ability of their progeny. Scientia agriculturae bohemica, 39(4), 304-309. www.sab.czu.cz/en/r-8044archive/r-8064-older-issues/r-11670-04-2008\#i8e3e36041282159455001dfa35e02aa8

Szabó, F., Nagy, L., Dákay, I., Márton, D., Török, M. \& Bene, S.Z. (2006). Effects of breed age of dam birth year, birth season and sex on weaning weight of beef calves. Livestock Science, 103(1-2), 181-185. DOI: 10.1016/j.livsci.2005.12.005

Szabolcs, B., Ferencz, S. \& Polgar, P. (2013). Some effects on calves' birth weight and calving difficulty of cows. 1 . The results of beef cattle in Hungry. Magyar Allatorvosok Lapja, 135(5), 267-277 www.researchgate.net/publication/286020886_Some_effects_on_calves\%27_birth _weight_and_calving_difficulty_of_cows_1_The_results_of_beef_cattle_in_Hung ry

Toušová, R., Ducháček, J., Stádník, L., Ptáček, M. \& Beran, J. (2014). The effect of selected factors on the growth ability of charolais cattle. ActaUniversitatisAgriculturaeetSilviculturaeMendelianaeBrunensis, 62(1), 255260. DOI: 10.11118/actaun201462010255

B.S. SR, S.E.: The Breeding Service of the Slovak Republic S.E. (2017). Results of breeding herd growth traits of Charolais breed in Slovak Republic at control years 2010 to 2016. 